\title{
A change agent's facilitation process for overcoming the barriers of ICT adoption for educational administration - The case of a rural-Bangladesh vocational institution
}

\author{
Md. Saifuddin Khalid and Tom Nyvang \\ Aalborg University, Denmark
}

\begin{abstract}
The factors influencing the use of information and communication technologies (ICT) as a professional and management tool outside the classroom have received little research attention. The two objectives of this research were: how do stakeholders of educational administration experience the barriers of ICT adoption, and how can they facilitate the transformation process in addressing the barriers that prevent the adoption? Taking a case from the development context of rural Bangladesh, the investigation is based on three theoretical stances: educational administration, the diffusion of innovations, and Participatory Rural Appraisal (PRA). Field-study based change agent facilitation applied PRA as a two-way diffusion communication method. The study concludes that barriers originate from the levels of individuals, the educational institution, the national agencies, and the external environment. PRA provided a useful framework facilitating communication to highlight barriers and gain a deeper understanding of what exactly the barriers at different levels are in a specific institution and how they influence practice.
\end{abstract}

\section{Introduction}

Research on educational technology has explored the barriers of integration and adoption of information and communication technologies (ICT) in teaching and learning activities (Balanskat, Blamire, \& Kefala, 2006; Bingimlas, 2009; Chan, 2011; Ertmer, Ottenbreit-Leftwich, Sadik, Sendurur, \& Sendurur, 2012; Ertmer, 2005; Hew \& Brush, 2006; Looi, So, Toh, \& Chen, 2011; Snoeyink \& Ertmer, 2001). The barriers are classified in various ways: classroom or individual (micro-), school (meso-) and national (macro-) level barriers (Lim, 2006; Younie, 2006); teachers' internal and external barriers (Ertmer et al., 2012; Ertmer, 2005; Snoeyink \& Ertmer, 2001); direct and indirect barriers (Hew \& Brush, 2006); material and non-material barriers (Pelgrum, 2001). Hew and Brush (2006) found the barriers to be related to:

- A lack of resources (i.e. technology, access to available technology time or person people, and technical support),

- knowledge and skills (on technology, technology-supported pedagogy, and technology-related classroom management),

- institution (including leadership, school time-tabling structure, and school planning),

- attitudes and beliefs (about teaching and learning and about technology),

- assessment (involving pressure to meet higher standards and high scores in state tests, meet vast material requirements, conformance of technology integration with external requirements of traditional exams),

- subject culture (shaped by content, pedagogy, and subject assessment) - both from the perspectives of the stakeholders and organizations of the education system.

In addition, government policy on ICT in education faces implementation problems of management, funding, technology procurement, ICT training and impact on pedagogy (Younie, 2006). "While most studies primarily focus on the use of ICT in teaching and learning, little attention has been given to their incorporation as a professional tool outside the classroom" (Meneses, Fàbregues, Rodríguez-Gómez, \& Ion, 2012, p. 915). Based on a review of literature, the professional use of ICT can be categorized into two types: firstly, supportive use including preparation activities for the classroom; and secondly, management use, referring to "teachers' general duties in the functioning of schools as organizations" (Meneses et al., 2012, p. 916). The management use encompasses the conduct of management and administrative tasks (Prokopiadou, 2012; Saiti \& Prokopiadou, 2009), communication with experts and colleagues (Law, Pelgrum, Plomp, \& International Association for the Evaluation of Educational Achievement, 2008), and interaction with students and parents (Ward \& Parr, 2010). This study deals with the adoption of ICT in management and administrative tasks. In particular, the research case 
explores a secondary institution's administration challenges in adopting the web-based tools and accessing the online information of a national education board. Such an adoption process involves the transformation of the educational administration system of the organisation.

The educational technology literature lacks a theoretically established definition of educational administration. In addition, there is scarce account of empirical findings on the ICT adoption barriers faced by the rural educational institutions of developing countries (Bingimlas, 2009; Hew \& Brush, 2006). Moreover, former empirical investigations on ICT integration and adoption barriers relied solely on interviews and/or surveys and are lacking mixed-methods-based research (Hew \& Brush, 2006; Mwalongo, 2011). Within this scope, this paper begins with a theoretically founded definition of educational administration and applies mixed-methods in order to address the following two contextdependent research questions. Firstly, how do the stakeholders of the educational administration of a rural secondary educational institution experience the ICT adoption barriers? Secondly, how to facilitate ICT adoption decisions and subsequent transformation processes in a school?

This paper is divided into the following six sections. First, the scope of the present paper is based on a theoretically founded definition of educational administration and a systematic review of ICT in educational administration. Second, the motivation for selecting and building on a situated single case in Bangladesh, particularly the selection of a rural, private, and technical vocational education and training (TVET) institution is discussed. Third, the application of mixed methods, i.e., the participatory learning and action (PLA) methods and their validation processes are briefly presented along with an introduction to the case and the participants in the methods used. Fourth, data are analyzed using a definition of educational administration and Rogers' (1995) theory of diffusion of innovations, focusing on the innovation process in an organisation. Fifth, the change agent role of the first author is analyzed in the context of organisational innovativeness (Rogers, 1995). In conclusion, the findings are summarized and future scope is suggested.

\section{Educational Administration}

\section{Definition of Educational Administration}

Our definition of educational administration takes as its point of departure the open systems model (Lunenburg \& Ornstein, 2012) that originated from systems theory (Senge, 2006). The open systems model shares core components with Roger's diffusion theory - the change process, the interconnected components of a system and the focus on communication. This consideration, however, does not discard the resemblance and applicability of other definitions and models of educational administration.

Systems theory defines schools as learning organisations; the learning organisation must be studied as a whole by taking into account the inter-relationships among its components and its relationship with the external environment (Senge, 2006). The open systems model presents a simple systems view of school administration (see Figure 1). It shows that a school is an open system of interactive components, including input, a transformation process, output, feedback, and the external environment. In addition, Figure 1 shows that the school's administrative roles, as part of a learning organisation, are inter-related at multiple levels - at the levels of school, state agencies and external environment (Lim, 2006). This study explores the ways in which the ICT adoption barriers are rooted to the before mentioned components, and how the transformation process can be facilitated for addressing these barriers.

To define the term organisation and to understand the process of ICT adoption in the organisation (see Data Analysis section), a second point of departure is taken from the theory of diffusion of innovations.

[A]n organization is a stable system of individuals who work together to achieve common goals through a hierarchy of ranks and a division of labor. Individual behavior in an organization is relatively stable and predictable because organizational structure is characterized by predetermined goals, prescribed roles, an authority structure, rules and regulations, and informal patterns. (Rogers, 1995, p. 403) 
Having defined the educational administration as an open system and an organisation, we have also indicated that interconnected processes and levels are crucial to this study of barriers and ways to circumvent them.

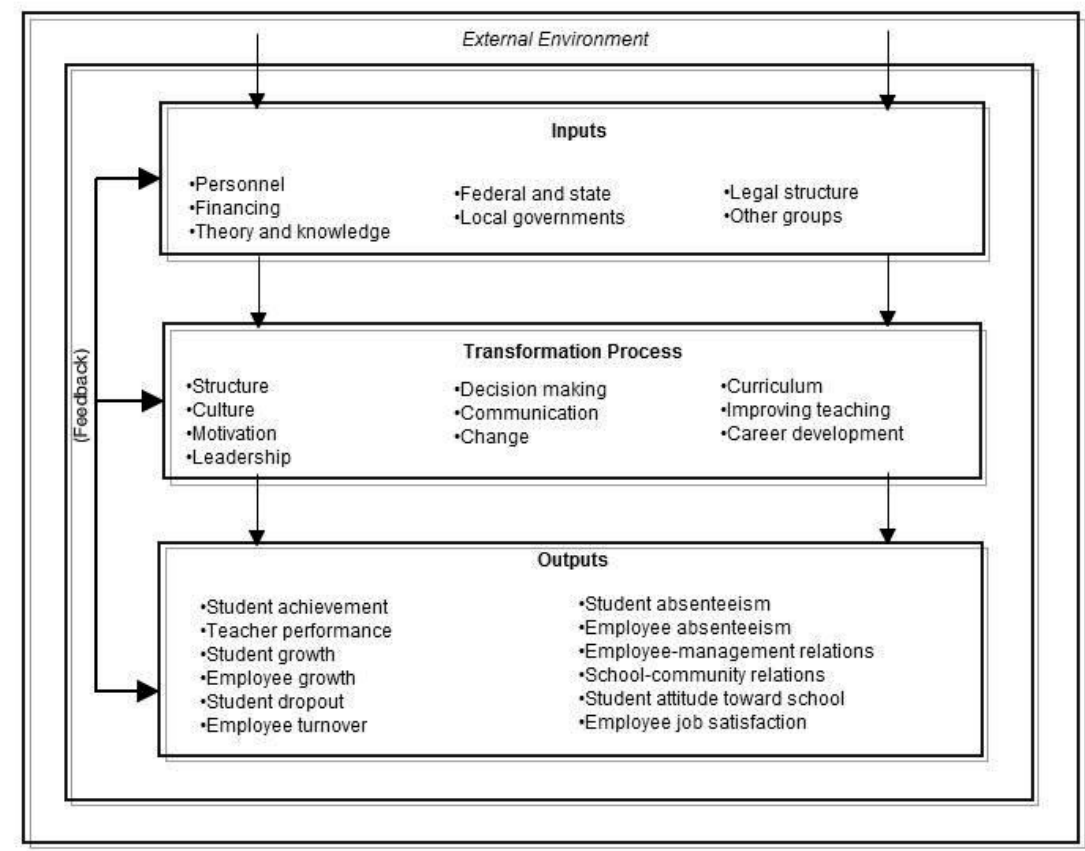

Figure 1. Systems view of school administration (Lunenburg \& Ornstein, 2012, p. 21)

\section{Systematic review of literature}

The extensive review reported in the introduction has provided an overview of the barriers to adoption of ICT in teaching and learning activities, categorized into micro-meso-macro level barriers, teachers' internal and external barriers, direct and indirect barriers, and material and non-material barriers, etc. This review section adds to the administrative theme, specifically the management use of ICT for the general functioning of schools as organisations.

A systematic review was conducted using different combinations of the keywords educational administration, school administration, and ICT adoption. Searches returned peer-reviewed articles from ScienceDirect (797 articles), Scopus (5 articles), ProQuest (3125 articles), Google Scholar (17200 articles) and ERIC (456 articles), published during the year 2000 or later. First 500 titles and abstracts were considered from each of the databases. Only four empirical articles and one review article matched the scope of this study.

Firstly, Meneses et al. (2012) analyzed the relationship between Spanish primary and secondary level teachers' attitudes towards, and professional uses of, the Internet. The study revealed that "even after controlling the effects of socio-demographics and school-level information, a school's organizational development is related to more frequent professional uses among teaching staff"; there exists "a connection between daily organizational practices and the unequal appropriation of ICT outside the classroom"; "frequency of Internet access within and outside school has a similar effect on positive attitudes towards the professional use of ICT", as the affordances of technologies are perceived over time; while within-school Internet access is associated with both types of professional use, outside school access is not associated with the management use of the Internet"; the location where the Internet is accessed plays a significant role in the types of teachers' professional practices outside the classroom"; "teachers who have attended useful-rated ICT courses, and especially those who reported a higher level of 
Internet mastering, show more positive attitudes and more frequent supportive and management uses" (Meneses et al., 2012, pp. 921-922).

Secondly, Saiti and Prokopiadou (2009) surveyed Greek secondary educators and analyzed the relationship between the adoption of ICT in school administration and different factors representing unfavourable environment. They found that the existing ICT of a school can serve administrative needs if technological equipment is located in the principal's office, and if there is ICT equipment exclusively for administrative purposes. However, there is a strong negative effect if technical support is dependent on experts from a private company. Teachers' familiarity with the use of computers for administrative purposes is positively associated with the following factors: the teacher is relatively young, the teacher is a male, the belief that a computer is important in administration, the teacher's participation in relevant training programs, and whether the school is located in an urban or semi-urban area.

Thirdly, Prokopiadou (2012) iterated a similar study on 230 Greek kindergarten principals and identified that the lack of technological equipment is caused by two things: poor management on the part of the Ministry of Education in the distribution of the available equipment to kindergartens, and limited financial support from the State. The educator's knowledge and familiarity with computers is explained by the following common responses: the training program they had attended was inadequate, they were either approaching retirement or had not attended any relevant training program because there was no such program in their area, or they had applied to attend a training program but their application was not accepted by the service in charge. It investigated the dependency of the degree of educators' familiarity with computers on: the age and the gender of the respondents; their perception of the importance of ICT to school administration; how frequently they used ICT for their administrative tasks; and whether or not the management of their administrative information was based on an information system (Prokopiadou, 2012). The result was that the young and the male educators are more likely to be more familiar with the use of computers. In addition, the presence of an administrative information system increases the likelihood of educators' familiarity with computers.

Fourthly, Ranjit Singh and Muniandi (2012) identified that lack of facilities, insufficient time to master and apply knowledge due to heavy teaching hours and attitudes of teachers are the barriers to technology adoption for Malaysian schools' administration.

Fifthly, Ghavifekr, Afshari, Siraj and Seger (2013) presented a conceptual review on the applications and effectiveness of ICT tools for school administration and management, as part of the 2020 Digital Malaysia initiatives. Various advantages experienced by the teachers and administrative staff regarding ICT mediated administrative activities were reviewed but the barriers and ways to circumvent the barriers remained unaddressed.

The review experience resulted in the identification of differences between the issues of the ICT adoption in the educational administration and in the teaching and learning activities. For instance, Prokopiadou (2012) argued:

[T] he difference between ICT in teaching-learning and in administration, in terms of professional training, may be noticed in the level of practical application, where the requisite skills and knowledge of relevant software applications differ according to the implementation domain, namely, teaching-learning or school administration. (p. 309)

The findings of these papers might be viewed as an initial exploration of the factors that affect the teachers and the administrative roles of educational institutions to use ICT as a professional tool in compulsory education (Meneses et al., 2012). Additionally, more studies are needed in order to explore the relationships and patterns that may explain changes. Moreover, more theoretical approaches need to be employed for exploring the organisational factors (Meneses et al., 2012). Furthermore, as most of the reviewed papers are survey-based and dependent on statistical significance:

[A] qualitative approach based on interviews and observations would extend our knowledge beyond statistical significance and general in-depth understanding about the meanings and values of the actors involved. (Meneses et al., 2012, p. 922) 
The reviewed literature also lacks a qualitative research that demonstrated a process to address the barriers confronted by facilitating educational institutions. While the survey-based large-sample studies provide breadth, qualitative exploration from even a single-case study can provide depth (Flyvbjerg, 2006). Current research builds on a long-term field based change agent facilitation to the educational administration stakeholders of one rural educational institution. This research attempts to contribute more depth concerning the ICT adoption barriers, the nature of their relationships and the change agent experience. In addition, the case which is the subject of this research is situated in a developing country and the research focuses on the transformation process in that institution.

\section{Motivation behind the context selection}

The motivation behind the context selection is discussed in two subsections. First, international priorities in ICT in education and Digital Bangladesh focus on educational administration and Technical Vocational Education and Training (TVET). Second, the demand by the great number of institutions in need: rural, disadvantaged and private institutions in Bangladesh.

\section{Digital Bangladesh: ICT in educational administration and TVET education}

The case selection of the present research was motivated by international priorities and Bangladesh's national agenda for ICT in education and TVET.

ICT in education is increasingly emphasized by the developing countries of the Asia Pacific region (Akhtar \& Arinto, 2009). One example is Vision 2021: Digital Bangladesh, which sets out the agenda for "improving the education sector through ICT in education" (A2I: PMO, 2009; BOI: PMO, 2009). The Access to Information (A2I) project of the Prime Minister's Office (PMO) of Bangladesh is responsible for coordinating the initiatives of this vision. The A2I project's Strategic Priorities of Digital Bangladesh: Improving Education Sector had six focus areas for facilitating the adoption of ICT in education: general and TVET education systems, the professional development of teachers using ICT, education related citizen services, ICT literacy for students, ICT infrastructure and delivery channels, and ICT in the educational administration (A2I: PMO, 2009). In addition, it placed special emphasis on TVET (A2I: PMO, 2009). Moreover, the strategic themes and the action plans of the national ICT policy of the Bangladesh Government - 2009 (MoICT, 2009) explicitly mentioned the education and research objectives supporting the present case. Furthermore, 2005-2014 is the United Nations Decade of Education for Sustainable Development; TVET has been nominated as one of the key areas for a collective UNESCO effort (Hollander \& Mar, 2009). The European Commission (EC) recognized its significance by providing financial support for the TVET reform project of Bangladesh (Mia, 2009).

Exploring the barriers in the context of Bangladesh was the central reason for situating the present study at a TVET institution. Bangladesh Technical Education Board (BTEB) was the first to integrate and to authoritatively decide that the TVET institutions have to use web-based systems for educational administration, starting from mid-2011. To the best of researcher's knowledge, no research on ICT adoption for the educational administration of technical educational institutions of Bangladesh has been published.

\section{Disadvantaged rural and private educational institutions}

About $70 \%$ of the world's poor population live in disadvantaged rural areas (World Bank, 2012), which deserve greater attention. Bangladesh has a population of about 142 million (BBS, 2011), and about $72 \%$ live in rural areas (World Bank, 2012). More than 91\% (2730 of 2981) of TVE institutions of Bangladesh are private, accommodating about $80 \%$ of teachers and more than $70 \%$ of students in technical study programs (BANBEIS, 2011a). In addition, more than 55\% of the TVE institutions are located in the rural areas (BANBEIS, 2011b). Therefore, a situated qualitative study on a TVE institution in Bangladesh could very well be situated in rural areas and be private sector. 


\section{Methodology}

\section{Research paradigm and methods}

From our definition of educational administration and the literature review we have some general ideas of what the barriers to ICT may be; however we aim for more qualitative and concrete insights into the nature of barriers. To reach such insights we chose to engage in the practice of changing an educational administration system ourselves. We did so to for three reasons. First, personal engagement in a rural educational administration in Bangladesh was needed if we wanted to study a change process in such an administration. Without intervention we had no change to study. Second, being part of the intervention, the first author became part of the process rather than studying it from the outside, which provided an opportunity to continuously interpret data, test interpretations and intervene and evaluate interventions. The first author took the role of a change agent (Rogers, 1995, Chapter 9), by living and working as consultants of a rural and private TVET institution in Bangladesh. Within action research design, two live-in field studies were conducted during August 2011- January 2012 and August-September 2012. Our third reason for an intervention based approach is in the words of the transformative paradigm that we "believe that inquiry needs to be intertwined with politics and a political agenda" (Creswell, 2003, p. 9), and the research should engage an action plan for change "that may change the lives of the participants, the institutions in which individuals work or live, and the researcher's life" (Creswell, 2003, pp. 9-10).

The transformative paradigm also advocates a participatory approach and mixed methods for the development of "more complete and full portraits of our social world through the use of multiple perspectives and lenses" (Somekh \& Lewin, 2005, p. 275) for exploring "greater diversity of values, stances and positions" (Somekh \& Lewin, 2005, p. 275). The transformative paradigm does, however, not in itself prescribe how to intervene and how to collect data. We thus turned to methods and the principles from participatory learning and action (PLA), formerly known as Participatory Rural Appraisal (PRA) for our data collection (Chambers, 2008; Narayanasamy, 2009). The PRA methods were applied to gain from two-way diffusion communication between the stake holders of the TVET institution and the change agent. Through these methods, the parties facilitated each other's understanding of innovation. The methods included focus group discussion (FGD), problem tree analysis (PTA), semi structured interview (SSI), and cultural transect.

The participants were: the founder, the management committee chairman, the principal, the consultant (the first author), one assistant professor (management), one lecturer (accounting), one assistant teacher (mathematics), one trade instructor (electrical), one part-time teacher (computer), one office assistant, and one MLSS (member of lower subordinate staff). With the founder and the chairman, the change agent conducted unstructured and semi-structured interviews only. The analysis section discusses the process of selecting these participants.

\section{The case}

A typical rural private TVET institution was selected. Prior to the field research, the authors arranged a sponsorship for the institution to become part of a national public-private partnership program called computer literacy program (CLP, 2010). By June 2011, CLP provided resources for establishing a smart class room (SCR) and a computer literacy center (CLC). SCR included one 32-inch LCD TV, one laptop, a 200 watt hybrid solar system, one VGA cable, one audio cable, four trained teachers, and a one-year maintenance contract (CLP, 2011b). The CLC setup included 4 laptops, one laser printer, one EDGE modem, one flash drive, and the training of two teachers (CLP, 2011a). The objectives were to integrate and diffuse ICT through the use of SCR in classroom teaching and through the use of CLC in non-formal training to 8-student batches. At the beginning of the field study, in August 2011, the change agent (CA) and participants summarized the current condition of the lab as following: the only computer lab for the trade subject has five fully functioning desktops. One desktop and one printer are used from the principal's room for all administrative activities, EDGE modems could not be connected to the Internet, the only office assistant with computer skills left recently, and 5 of 8 computer-skill positions were vacant. In addition, the existing three ICT teachers agreed that "without external help, on our own, it might not be possible to improve the situation". 
With the abovementioned ICT resource conditions at the client end, BTEB discontinued paper-based administrative activities with the TVET institutions in Bangladesh. Despite training from BTEB, the institution faced significant barriers and started hiring services from a nearby market for computer, internet and Xerox. Therefore, the present study analyzes the way in which ICT adoption in educational administration activities incidentally became an agenda and how the transformation process was facilitated by the present research initiative.

\section{Analyzing the innovation process and change agent facilitation}

This section discusses the innovation adoption facilitation process based on the theory of the diffusion of innovations, namely the change agent facilitation and the steps of the innovation process in an organisation (Rogers, 1995, Chapter 10). "Data about the innovation process are obtained by synthesizing the recallable perceptions of key actors in the innovation process, written records of the organization adoption, and other data sources" (Rogers, 1995, p. 390). In the present paper, data about the innovation process includes the participants' experiences (including those of the change agent) from the PRA methods, the recorded events, and the change agent's recollected perceptions of events.

The analysis involves two theoretical foundations: a definition of educational administration and the theory of the diffusion of innovations. Based on the systems view of school administration (Figure 1) as part of the definition of educational administration, BTEB's ICT-mediated administration initiative is considered as input that initiated the school's administrative transformation process in decision making, communication, change and structure. The transformation process can be identified through Roger's (Rogers, 1995, p. 392) five stages of the innovation adoption process in the organization.

The innovation process in an organization consists of two broad activities: (1) initiation, defined as all of the information gathering, as well as the conceptualizing, and planning for the adoption of an innovation, leading up to the decision to adopt, and (2) implementation, all of the events, actions, and decisions involved in implementing innovation. The initiation stage is further divided into 1. agenda-setting and 2. matching stages; implementation occurs over the three stages of redefining/restructuring, clarifying, and routinizing. (Rogers, 1995, p. 392)

Therefore, the innovation adoption process and the change agent experiences are presented in five sections, corresponding to each of the five innovation adoption stages.

\section{Agenda-Setting: General organisational problems that may create a perceived need for innovation}

The agenda-setting for the institution's transformation process (see Figure 1) through ICT adoption for educational administration began from a mere informal discussion between the CA and the principal of the institution. The discussion has been translated from Bengali and transcribed as follows.

Principal: Brother, I am going to Majjara market. I have to finish the BTEB's online registration forms by today and have them ready for their [BTEB's] processing from tomorrow. ... So, I might not be meeting you before tomorrow and I wanted to say bye for today.

CA: But can we not do that here? As a TVET institution IT skills should be one of our core competences. Principal: I guess, no. We can't scan, edit images, or even get Internet connection. In fact, you might end up finding that our TVET institutions are mostly theoretical, getting away with memorization, and possibly provide rather frustrating levels of skills.

CA: Is that so! Anyway, I get Internet connection in my mobile. I can also access the Internet from my laptop by using both of my mobiles. Not that good, but it might be worth trying. I just felt that I might be able to get these things done, somehow.

Principal: Oh really! That sounds great. If you can find a way for us, it would surely save a lot of money, hassle, and time. But, we really have to finish that today.

CA: Please come inside the lab with me. Let's try.

In brief, the subsequent events were as follows. In the absence of computer-skilled administrative personnel, the CA asked for assistance from a tenth grade student. The CA had identified the student to be 
exceptionally tech-savvy about the Internet and to possess strong skills with regards to computer applications. The CA demonstrated the process to the student, the principal and the accounting lecturer. Scanning of passport-size photos of students was carried out using a mobile phone camera, and editing was done using the default image editor of the Windows operating system. Initially, the Internet was accessed through Wi-Fi hotspot of the CA's mobile, until the charge depleted. Later, an Internet connection was established by using the student's mobile, until that too ran out of charge. Finally, due to the lack of power supply from the national grid, the EDGE modem from the CLP project was used with the CA's SIM. The images were stored in a flash drive to ensure backup. By the time the entire process had been completed, the battery backups of two laptops were consumed before automatic shutdown. This process took more than 12 hours of uninterrupted effort for at least two persons at a time - among them the student, the principal, the CA, and the lecturer (accounting). The student dedicatedly completed the task without a break. The following day, a three-person team attended a demonstration and experienced printing from the BTEB web-application. One copy was prepared to be sent to BTEB and the other was filed for the institution. Later, a staff meeting was scheduled for discussing the experience, and decisions about adoption of the before mentioned ICT based strategy and other administrative strategies and technologies within the institution, as well as prospective strategies for a sustainable change, were outlined.

The above-mentioned events involved a creative mix of available technologies, available skills, and facilitated confidence-building. This might be viewed as part of the redefining stage, which involves modification of the innovation.

Agenda-setting is a continuous process in which "one or more individuals of an organization identify an important problem and then seek an innovation as one means of coping with the problem" (Rogers, 1995, p. 393). In the present case, the identified problem might be generalized as follows: the outsourcing of the ICT-mediated administrative activities of education-board-administered institutions involves higher cost, prolonged completion time, and the risk of misuse of authentication credentials, etc. The diffusion theory defines these problems as the performance gap which triggered the change.

\section{Matching: Fitting a problem from the organisation's agenda with innovation}

The matching stage:

[I]s a type of reality testing in which the members of an organization attempt to determine the feasibility of the innovation in solving the organization's problem. Such symbolic planning entails consideration as to the anticipated problems that the innovation might encounter if it were implemented. (Rogers, 1995, p. 394)

The institution's identified problem was the performance gap in the outsourcing of ICT mediated educational administration. The intended solution was the adoption of in-house operation with sustainable change.

BTEB's decision on the ICT mediated administrative information system was discussed during an institution staff-meeting. The change-agent-facilitated experience of the in-house operation was discussed, and a need for a 'strategic adoption plan' was raised. The meeting participants suggested that the members of the academic committee and other routine administrative role players should deal in a dedicated way with this matter. In September 2011, six teachers and two staff were scheduled for participating in PRA exercises with the change agent. The participants' identified problem, the performance gap, is related to the outsourcing of the services. Therefore, as the agenda of the subsequent meetings, the feasibility study involved the following questions to find out if more administrative processes could be handled in-house: (1) How do the personnel perceive the educational administration process? (2) What are the known/foreseen barriers of the in-house ICT adoption for educational administration? (3) What could the in-house ICT adoption strategy be?

First, the administration process is explored by triangulating three methods, i.e. FGD, interview and participant observation. The CA facilitated FGDs among participants, conducted interviews with the founder (retired BTEB director) and the chairman, and studied (together with the principal) the BTEB's administrative documents. The institution's administration process was divided into two categories: 
organisational administration and academic administration. For theoretical underpinning, the present paper uses the term educational instead of academic. The organisational administration process encompasses traditional organisational department roles, which are human resource management, accounts and finance, inventory, planning and development, facilities, store and purchase, and cultural affairs. The educational administration discussed was limited to the essential use of computer and Internet for coordinating with BTEB (see Table 1). These processes and activities included the role of an academic committee and an examination committee, which would require facilitation for in-house ICT capacity-building.

Table 1

Identified processes of web-dependent educational administration

\begin{tabular}{|c|c|}
\hline Process Name & ICT mediated activities \\
\hline $\begin{array}{l}\text { Curricula, regulations, } \\
\text { and notices }\end{array}$ & $\begin{array}{l}\text { Curricula and policy, updates \& notices; Probidhan, details used for standard } \\
\text { operating procedures, from admission to BTEB results (e.g. SSC Voc } \\
\text { Probidhan from 2013) }\end{array}$ \\
\hline Annual planning & Annual calendar. \\
\hline Class Scheduling & Class scheduling guidelines. \\
\hline Curriculum content & $\begin{array}{l}\text { Search and collect from website, print and manage - core documents, } \\
\text { amendments, policy updates, and notices. }\end{array}$ \\
\hline Syllabus & $\begin{array}{l}\text { Collect, print, disseminate and manage - Core syllabus, amendments, marks } \\
\text { distribution. }\end{array}$ \\
\hline Admission & $\begin{array}{l}\text { Notices on instructions and deadlines, admission form record entry, } \\
\text { prospectus collection, additional news, and document printing and } \\
\text { management. }\end{array}$ \\
\hline Registration & $\begin{array}{l}\text { Registration Information Form (RIF): Registration records with date, } \\
\text { students' individual records in a text form, uploading of scanned photos, } \\
\text { printing and management of forms. }\end{array}$ \\
\hline $\begin{array}{l}\text { Assessment and } \\
\text { Evaluation }\end{array}$ & $\begin{array}{l}\text { (Public) Examination Information Form (EIF): Notices on instructions and } \\
\text { deadlines, student record entry, management of printed forms. } \\
\text { Marks entry: Continuous assessment and separate industrial attachment, final } \\
\text { assessment with separate industrial attachment. }\end{array}$ \\
\hline Publish Results & $\begin{array}{l}\text { (Year final exams') board results access, print and dissemination, Appeal for } \\
\text { result scrutiny and revision. }\end{array}$ \\
\hline
\end{tabular}

The result of the between-method triangulation was that there should be financial and human resource capacity to deal with the use of additional peripheral devices (e.g. printer, scanner, etc.), web-based applications, office applications, and basic troubleshooting. To explore such barriers or root-causes of inhouse adoption, the second agenda was raised: what are the known/foreseen barriers to the in-house ICT adoption for educational administration? In this regard, an FGD was facilitated to define a problem statement for a problem tree analysis (PTA). The problem statement was: the institution cannot adopt inhouse ICT capacity for ICT mediated educational administration.

In Figure 2, the problem tree diagram (Narayanasamy, 2009, p. 129) shows that the participants identified the causes to be rooted in individuals, the educational institution, the national educational agencies, and the external environment of the institution. The diagram provides qualitative insights of the interdependencies among the barriers. The barriers and effects were identified by the institution stakeholders whereas the principal researchers provided translation from the Bangladeshi language to English and added (most of) the higher level categorization. 


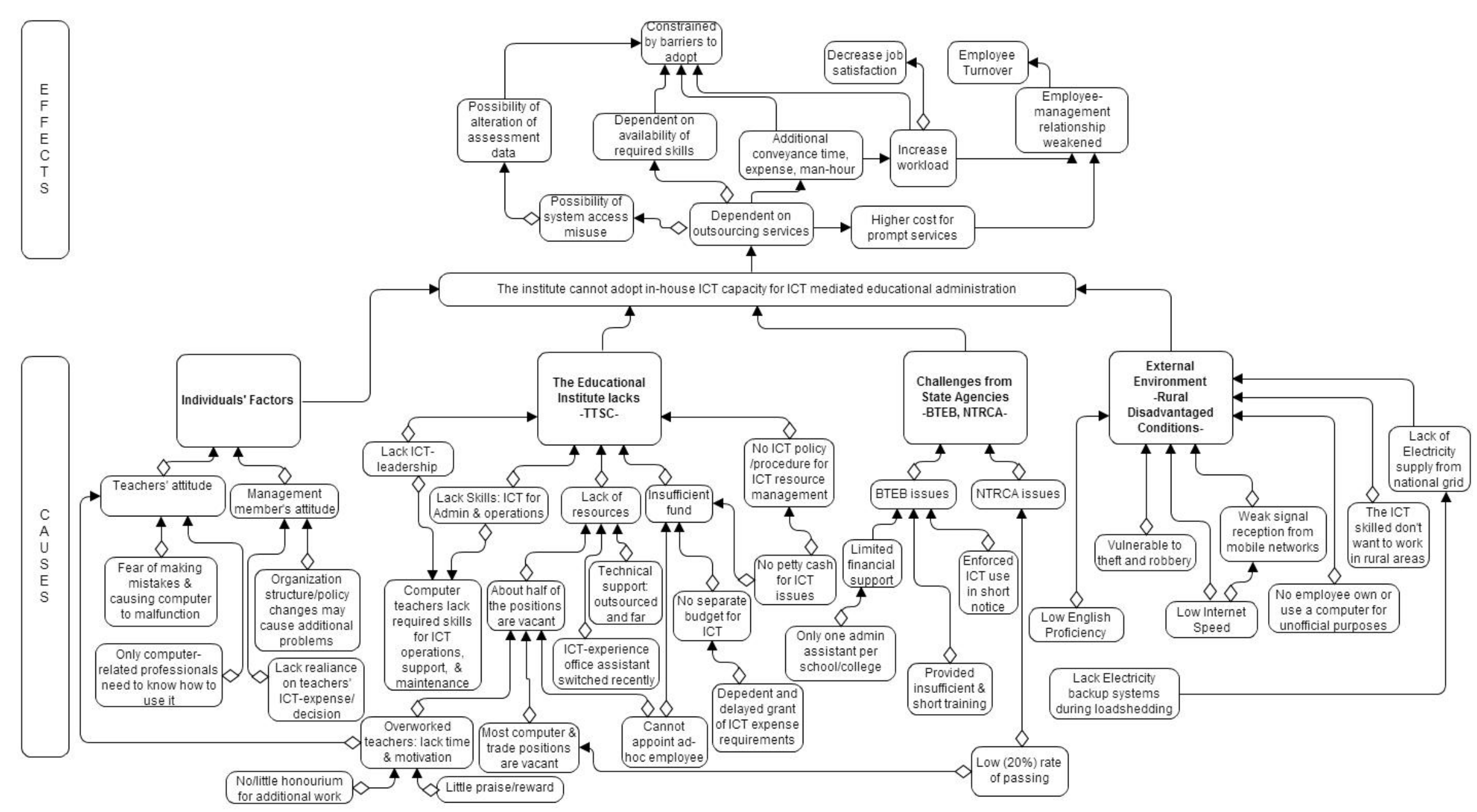

Figure 2. ICT adoption for educational administration: Problem Tree 
The findings are congruent with teacher or classroom (micro-), institution (meso-) and national (macro-) level barriers of learning technologies (Lim, 2006; Looi et al., 2011) and the barriers faced by the public polytechnics institutions of Bangladesh (Abdullah-Al-Mamun, 2012). At this stage, the challenge was to identify the key barriers to a sustainable change.

\section{Redefining or Restructuring: The innovation is modified and re-invented to fit the organisation, and organisation structures are altered}

Based on the PTA, the following question was discussed during two workshops: what can be a sustainable adoption strategy?

Firstly, the root causes were identified from the PTA (Figure 2): lack of: leadership, an ICT committee, funds, ICT-resource policy and procedure, an interested person to work in a rural area, skills for operation and management, knowledge and training for the role of ICT committee members, dependence on the management chairman for ICT-expenses, and reliable computers with power backup. From the systems view of school administration, the root causes might be viewed (as in Figure 2) as inputs for a transformation process.

Secondly, the workshops resulted in the formation of an ICT committee and the definition of the roles of the committee and its members. The policies and procedures of the ICT committee's documentation rendered the details of the strategy. With reference to the CA as the consultant, the following proposals were documented for the approval of the key decision makers of the school's management committee:

- The principal shall be the chair,

- $\quad$ and an elected teacher shall be the convener of the committee,

- the two (principal and elected teacher!) roles shall be responsible for a separate bank account,

- the financial issues of ICT shall be separated from the institution's bank account,

- the consultant shall identify and provide training to an ad-hoc ICT-mediated administrative employee,

- the committee shall be able to earn from the services to the institution and from any external source,

- the income shall be spent primarily for the salary of the employee and other ICT-resources.

In addition, it was proposed that an annual fee for ICT should be charged to each student. The reasoning was that the institution will take photos for the online forms, and students should not have to spend money at the photo studios. Moreover, a financial feasibility study was included, which compared estimated in-house costs and estimated outsourcing costs. Comparing three outsourcing options, the cost of communication, commuting, and services for about two years was calculated with a $7 \%$ increase in the second year. The in-house costs included hardware, software, and salary. Compared to outsourcing, the in-house adoption was acknowledged as significantly feasible - financially, operationally, and for maintenance. By January 23, 2012, the CA had identified and had trained one self-motivated HSCgraduate from the institution's 2009-computer-trade class. He voluntarily spent 17 hours per day, six days a week, and over three months on training and working. For his ad-hoc appointment, the CA allocated BDT 36,000 (USD 453) for the salary for the next twelve months. Except for Xerox, the ICT-mediated administrative activities did not have to depend on outsourcing. The BTEB-related tasks were primarily dealt with by the principal and the office-assistant for ICT. However, the institution did not submit the ICT committee proposal for approval and waited for the second field study of the change agent.

During the second field study, the CA facilitated revision of the proposal for the ICT committee, which included an ICT-mediated administration process, and submitted the proposal to the key management. The proposal was approved except for the creation of a separate bank account. The management chairman and the founder agreed on three reasons for not approving: "firstly, we cannot promise them any incentive for all the additional efforts they will dedicate for the ICT committee. ... secondly, this innovative idea might have a challenge in the annual audit by the government, else the institution might face difficulty....one more question, will the trust and power relationship among the teachers get affected because of the new role?" However, in January 2013, the idea of a separate bank account and the 
separation of the institution's central financial process were approved. Therefore, the process of the adoption decision for the restructuring of the organisational process took about one year.

\section{Clarifying: The relationship between the organisation and the innovation is defined more clearly}

The clarifying stage in the innovation process in an organization consists of social construction. Through a process of the people in an organization talking about the innovation, they gradually gain a common understanding of it. (Rogers, 1995, p. 399)

The participants found that the PRA exercises were convenient ways for questioning, reflecting on personal viewpoints, exploring the root causes of the problem, and suggesting a solution and in that respect the PRA exercises constructed the ICT based innovations in a new way in the organisation. It was added that involving all employees on certain occasions created an environment for informal discussions and the sharing of ideas or experiences, so the interaction also fostered new perspectives through social knowledge sharing and construction.

\section{Routinising: Innovation becomes an ongoing element in the organisation's activities, and loses its identity}

The innovation adoption process in an organisation is completed at the routinisation stage. In addition, discontinuance can occur, and the implementation sub-process may end in failure (Rogers, 1995, pp. 399400). In the present case, ICT-mediated administrative activities became an in-house process. However, the self-sustenance initiative through the separate financial process of the ICT committee did not reach a routinising stage till early 2013,that is, the process lasted about 18 months. The participants believe that discontinuance might not occur due to strong determination, a firm belief in the desired positive outcome and the strategies adopted. It was reasoned that it is less likely that the present level of required skills among the employees, the ICT-leadership strategy, and the ICT-resource strength will be lacking at the same time. However, it was added that the financial solvency of the ICT account and the turnover of the ICT-skilled employees are two objectives to be sustained.

\section{The role of change agent}

The success of the CA depends on some factors which Rogers (1995, Chapter 9) stated as generalisations. All the staff of the institution assessed the CA's contributions against a checklist of the generalisations, as part of an FGD that was facilitated by the ICT-committee and held in the absence of the CA. The participants' agreements and comments on the list of Rogers' generalisations are as follows. The success of diffusing ICT adoption was related to: client orientation with close rapport, high credibility level, and clients' need; the degree to which the diffusion initiatives were compatible with clients' need; the change agent's empathy in being a member of a disadvantaged, rural, educational institution; high competence credibility in the eyes of the clients; the extent to which work is carried out through opinion leaders, i.e. the stakeholders in the decision-making processes of the institutions; and increased client ability to evaluate innovations.

\section{Conclusion}

The paper has addressed two objectives: how (i.e. in which processes/activities and what causes) do stakeholders of educational administration experience the barriers of ICT adoption and how do they facilitate the transformation process and address the barriers that resist the adoption. To deal with these questions, the study involved three theoretical grounds: the definition of educational administration that views educational institutions as an open system (Lunenburg \& Ornstein, 2012), the innovation adoption process in an organisation (Rogers, 1995, Chapter 10), and the factors associated with the success of a change agent (Rogers, 1995, Chapter 9). In addition, the participatory learning and action (Chambers, 2008; Narayanasamy, 2009) methods and principles were applied for integrating the fundamentals of the three theoretically established concepts. More specifically, the change agent experience of the first author was used in the participatory learning and action methods as two-way diffusion communication for the transformation process of the organisational adoption process. 
The stakeholders found that the barriers originate from the levels of individuals, the educational institution, the national educational agencies, and the external environment of the institution. The barriers in teaching-learning activities are categorized in the same way as micro- (individual or classroom), meso(institutional) and macro- (national) level barriers (Lim, 2006; Looi et al., 2011). In addition, the barriers of the private institution are congruent with the barriers faced by public polytechnic institutions of Bangladesh (Abdullah-Al-Mamun, 2012), which are located in urban or semi-urban areas. Moreover, there are many-to-many dependency relationships among barriers (as in Figure 2) that alone could probably impede meaningful adoption and use of ICT. The problem-tree analysis method shows that the barriers are interconnected to the components of the learning organisation (Senge, 2006).

Supporting the claim of Flyvbjerg (2006), this single-case study provided significant depth and enabled the qualitative exploration of the barriers. The participant-identified root barriers to the in-house ICT adoption for educational administration include lack of: leadership, an ICT committee, funding, ICTresource policy and procedure, a person interested in working in a rural area, skills for operation and management, knowledge and training for ICT committee roles, dependence on a management chairman for ICT-expenses, and reliable computers with power backup. Addressing these barriers involved transformation in the open system of the institution (Lunenburg \& Ornstein, 2012). In addition, the complexities of the barriers in the developing context of rural Bangladesh are far greater than those reviewed. From the change agent's point of view, the facilitation involved a creative mix of the available technologies and skills, a leadership role within the school and in persuading the key decision-makers, the provision of problem-based and on-site training, purchase and transportation responsibility, and financial support for the resources.

For future reference in practice and policy making our study presents two main findings. Firstly, we have shown a complex web of barriers and it is reasonable to expect a similar complexity in other institutions and even that some of the barriers will appear in other cases. We cannot, however, fully predict the specific situated barriers in other cases and that brings us to our second contribution to practice and policy: The transformative paradigm and PRA offers a perspective and a tool-box that can be used to uncover the specific barriers to ICT in any educational institution in a developing country and help to overcome some of the barriers. The bad news so far is that there is no easy quick fix in sight that can quickly develop all educational institutions in rural Bangladesh.

\section{References}

A2I: PMO. (2009). Strategic priorities of digital Bangladesh: Improving education sector. Access to information, Prime Minister's office, Bangladesh. Government of Bangladesh. Retrieved from http://www.digitalbangladesh.gov.bd/documents/Education.pdf

Abdullah-Al-Mamun, M. (2012). Technology in educational settings in the government polytechnic institutes of Bangladesh: A critical analysis. International Journal of Computer Applications, 54(13). Retrieved from http://research.ijcaonline.org/volume54/number13/pxc3882502.pdf

Akhtar, S., \& Arinto, P. (Eds.). (2009). Digital review of Asia Pacific, 2009-2010. Delhi: SAGE Publications. Retrieved from http://site.ebrary.com/id/10314695

Balanskat, A., Blamire, R., \& Kefala, S. (2006). The ICT impact report. European Schoolnet. Retrieved from http://www.lopstechnology.com/fotos/editor2/relatorios/ict_impact_report_1_.pdf

BANBEIS. (2011a). Number of vocational institution, teacher and enrolment by type, management and sex - 2011. Bangladesh Bureau of Educational Information and Statistics. Government of Bangladesh. Retrieved from http://www.banbeis.gov.bd/webnew/index.php?option=com_content\&view=article\&id=628:table-65number-of-institution-teacher-and-enrolment-by-type-management-and-sex2011\&catid=99:technicaland-vocational-education-2011\&Itemid=202

BANBEIS. (2011b). Number of technical institution, teacher and enrolment by location. Bangladesh Bureau of Educational Information and Statistics. Government of Bangladesh. Retrieved from http://www.banbeis.gov.bd/webnew/index.php?option=com_content\&view=article\&id=456:numberof-institution-teacher-and-enrolment-by-location \&catid=77:- technical-and-vocational-education2010\&Itemid $=185$

BBS. (2011). 2011 Population \& housing census: Preliminary results. Bangladesh Bureau of Statistics. Government Official. Retrieved from http://www.bbs.gov.bd/WebTestApplication/userfiles/Image/Census2011/Bangladesh_glance.pdf 
Bingimlas, K. A. (2009). Barriers to the successful integration of ICT in teaching and learning environments: A review of the literature. Eurasia Journal of Mathematics, Science \& Technology Education, 5(3), 235-245.

BOI: PMO. (2009). Government Vision 2021. Board of investment, Prime Minster's office, Bangladesh. Government of Bangladesh. Retrieved May 19, 2012, from http://boi.gov.bd/aboutbangladesh/government-and-policies/government-vision-2021

Chambers, R. (2008). PRA, PLA and Pluralism: Practice and Theory. In P. Reason \& H. Bradbury (Eds.), The SAGE handbook of action research : participative inquiry and practice (pp. 297-318). London: SAGE.

Chan, C. K. K. (2011). Bridging research and practice: Implementing and sustaining knowledge building in Hong Kong classrooms. International Journal of Computer-Supported Collaborative Learning, 6(2), 147-186. doi:10.1007/s11412-011-9121-0

CLP. (2010). CLC \& SCR Online pledge form « Computer literacy program. Computer literacy program, Bangladesh. NGO. Retrieved from http://www.clp.net.bd/clc-scr-online-pledge-form

CLP. (2011a). Computer literacy center of Tofail Ali technical school and college, B.Baria. Computer literacy program, Bangladesh. NGO. Retrieved March 16, 2012, from http://www.clp.net.bd/blog/2484/tofail-ali-technical-school-and-college-b-baria

CLP. (2011b). Smart class room of Tofail Ali technical school and college. Computer literacy program, Bangladesh. NGO. Retrieved March 16, 2012, from http://www.clp.net.bd/blog/2737/tofail-alitechnical-school-and-college

Creswell, J. W. (2003). Research design: Qualitative, quantitative, and mixed methods approaches. (2nd ed.). Thousand Oaks: SAGE.

Ertmer, P. A. (2005). Teacher pedagogical beliefs: The final frontier in our quest for technology integration? Educational Technology Research and Development, 53(4), 25-39. doi:10.1007/BF02504683

Ertmer, P. A., Ottenbreit-Leftwich, A. T., Sadik, O., Sendurur, E., \& Sendurur, P. (2012). Teacher beliefs and technology integration practices: A critical relationship. Computers \& Education, 59(2), 423-435. doi:10.1016/j.compedu.2012.02.001

Flyvbjerg, B. (2006). Five misunderstandings about case-study research. Qualitative Inquiry, 12(2), 219 245. doi:10.1177/1077800405284363

Ghavifekr, S., Afshari, M., Siraj, S., \& Seger, K. (2013). ICT application for administration and management: A conceptual review. Procedia - Social and Behavioral Sciences, 103, 1344-1351. doi:10.1016/j.sbspro.2013.10.705

Hew, K. F., \& Brush, T. (2006). Integrating technology into K-12 teaching and learning: Current knowledge gaps and recommendations for future research. Educational Technology Research and Development, 55(3), 223-252. doi:10.1007/s11423-006-9022-5

Hollander, A., \& Mar, N. Y. (2009). Towards achieving TVET for all: The role of the UNESCOUNEVOC international centre for technical and vocational education and training. In R. Maclean \& D. Wilson (Eds.), International Handbook of Education for the Changing World of Work (pp. 41-57). Dordrecht: Springer Netherlands. Retrieved from http://www.springerlink.com/index/10.1007/978-14020-5281-1_3

Law, N., Pelgrum, W. J., Plomp, T., \& International Association for the Evaluation of Educational Achievement. (2008). Pedagogy and ICT use in schools around the world: Findings from the IEA SITES 2006 study. [New York]; Hong Kong: Springer ; Comparative Education Research Centre, the University of Hong Kong. Retrieved from http://www.myilibrary.com?id=187602

Lim, C. P. (2006). Effective integration of ICT in Singapore schools: Pedagogical and policy implications. Educational Technology Research and Development, 55(1), 83-116. doi:10.1007/s11423-006-9025-2

Looi, C.-K., So, H.-J., Toh, Y., \& Chen, W. (2011). The Singapore experience: Synergy of national policy, classroom practice and design research. International Journal of Computer-Supported Collaborative Learning, 6(1), 9-37. doi:10.1007/s11412-010-9102-8

Lunenburg, F. C., \& Ornstein, A. C. (2012). Educational administration : Concepts and practices (6th ed.). Belmont, CA: Wadsworth.

Meneses, J., Fàbregues, S., Rodríguez-Gómez, D., \& Ion, G. (2012). Internet in teachers’ professional practice outside the classroom: Examining supportive and management uses in primary and secondary schools. Computers \& Education, 59(3), 915-924. doi:10.1016/j.compedu.2012.04.011

Mia, A. (2009). Qualifications frameworks: Implementation and impact background case study on Bangladesh. Retrieved from 
http://www.ilo.org/wcmsp5/groups/public/@ed_emp/@ifp_skills/documents/genericdocument/wcms_ 126590.pdf

MoICT. (2009). Bangladesh National ICT Policy 2009. Ministry of information \& communication technology, Bangladesh. Retrieved from

http://www.ictd.gov.bd/administrator/components/com_filecabinet/uploads/National_ICT-Policy2009-Bangla.pdf

Mwalongo, A. (2011). Teachers' perceptions about ICTs for teaching, professional development, administration and personal use. International Journal of Education and Development Using Information and Communication Technology (IJEDICT), 7(3), 36-49.

Narayanasamy, N. (2009). Participatory rural appraisal : Principles, methods and application. Los Angeles: SAGE.

Pelgrum, W. (2001). Obstacles to the integration of ICT in education: Results from a worldwide educational assessment. Computers \& Education, 37(2), 163-178. doi:10.1016/S0360$1315(01) 00045-8$

Prokopiadou, G. (2012). Using information and communication technologies in school administration: Researching Greek kindergarten schools. Educational Management Administration \& Leadership, 40(3), 305-327. doi:10.1177/1741143212436953

Ranjit Singh, T. K., \& Muniandi, K. (2012). Factors affecting school administrators' choices in adopting ICT tools in schools - The case of Malaysian schools. International Education Studies, 5(4). doi:10.5539/ies.v5n4p21

Rogers, E. M. (1995). Diffusion of innovations (4th ed.). New York: Free Press.

Saiti, A., \& Prokopiadou, G. (2009). Impact of information and communication technologies on school administration: Research on the Greek schools of secondary education. In M. A. Wimmer, H. J. Scholl, M. Janssen, \& R. Traunmüller (Eds.), Electronic Government (Vol. 5693, pp. 305-316). Berlin, Heidelberg: Springer Berlin Heidelberg. Retrieved from http://www.springerlink.com/index/10.1007/978-3-642-03516-6_26

Senge, P. M. (2006). The fifth discipline: The art and practice of the learning organization. New York: Doubleday/Currency.

Snoeyink, R., \& Ertmer, P. A. (2001). Thrust into technology: How veteran teachers respond. Journal of Educational Technology Systems, 30(1), 85-111. doi:10.2190/YDL7-XH09-RLJ6-MTP1

Somekh, B., \& Lewin, C. (2005). Research methods in the social sciences. London: SAGE.

Ward, L., \& Parr, J. M. (2010). Revisiting and reframing use: Implications for the integration of ICT. Computers \& Education, 54(1), 113-122. doi:10.1016/j.compedu.2009.07.011

World Bank. (2012). Agriculture \& rural development | Data. Retrieved December 6, 2012, from http://data.worldbank.org/topic/agriculture-and-rural-development

Younie, S. (2006). Implementing government policy on ICT in education: Lessons learnt. Education and Information Technologies, 11(3-4), 385-400. doi:10.1007/s10639-006-9017-1

Corresponding author: Md. Saifuddin Khalid, professorkhalid@gmail.com

Australasian Journal of Educational Technology (C) 2014.

Please cite as: Khalid, M.S., \& Nyvang, T. (2014). A change agent's facilitation process for overcoming the barriers of ICT adoption for educational administration - The case of a rural-Bangladesh vocational institution. Australasian Journal of Educational Technology, 30(5), 547-561. 